\title{
Heavy Metal Contamination of Foods by Refuse Dump Sites in Awka, Southeastern Nigeria
}

\author{
J.K.C. Nduka ${ }^{1}$, O.E. Orisakwe ${ }^{2, *}$, L.O. Ezenweke ${ }^{3}$, M.N. Chendo ${ }^{3}$, \\ and T.E. Ezenwa ${ }^{3}$ \\ ${ }^{1}$ Pure and Industrial Chemistry Department, Nnamdi Azikiwe University, Awka, \\ Anambra State, Nigeria; ${ }^{2}$ Toxicology Unit, Pharmacology Department, College of \\ Health Sciences, Nnamdi Azikiwe University, Nnewi Campus, Nnewi, Anambra \\ State, Nigeria; ${ }^{3}$ Chemistry Department, Anambra State University, Uli, Nigeria \\ E-mail: eorish@aol.com
}

Received July 26, 2008; Revised September 7, 2008; Accepted September 12, 2008; Published October 1, 2008

The impact of heavy metals from refuse dumps on soil, food, and water qualities in Awka, Nigeria was studied. Soil samples (top and $1.35 \mathrm{~m}$ deep) were collected from five refuse dumps digested with conc. $\mathrm{HNO}_{3}$ and $\mathrm{HClO}_{4}$. The heavy metals (lead, manganese, arsenic, chromium, cadmium, and nickel) in vegetables (spinach, fluted pumpkin), root crop (cocoyam), and surface and ground water were determined using an atomic absorption spectrophotometer (AAS). Chemical properties of the soil and bacteria were determined. Heavy metals were found to be more concentrated at a depth of $1.35 \mathrm{~m}$. Manganese was high in shallow wells and borehole water samples with the highest levels as 0.538 and $0.325 \mathrm{mg} / \mathrm{l}$, respectively. Nickel levels in the borehole sample ranged from 0.001 to 0.227 $\mathrm{mg} / \mathrm{l}$, whereas the highest level of lead was $0.01 \mathrm{mg} / \mathrm{l}$. The Obibia stream had the highest levels of manganese and lead. Linear regression analyses showed that the relationship between soil heavy metals and farm produce heavy metals was strong. Taken together, we may conclude that the consumption of leafy vegetables and crops produced on contaminated soils may pose a health risk to those that reside around the refuse dumps.

KEYWORDS: heavy metals, refuse dumps, farm produce, environmental pollution, Nigeria

\section{INTRODUCTION}

Plant uptake is one of the major pathways by which heavy metals in soils enter the human food chain[1]. Food crops such as cassava, cocoyam, and other tuber crops grown in mining communities take up toxic or hazardous chemicals, such as arsenic and cadmium, from the soil. This study evaluated the human health risk from eating cassava grown in some mining communities in Ghana[2]. Also, concerns over the possible increase in phytoavailability of biosolids-applied trace metals to plants have been raised based on the assumption that decomposition of applied organic matter would increase phytoavailability[3]. It has been found that uptake of gaseous mercury was the predominant pathway by which the mercury accumulated in the foliage, and mercury in root tissue is mainly derived from soil[4]. Cadmium pollution 
of soil affects the soil-plant pathway[1]. Shute and Macfie's work on the cadmium and zinc accumulation in soybeans reinforces the need to monitor concentrations of toxic metals in food crops[5]. The uptake of heavy metals by lettuce and mustard rape in sewage sludge and effluent-exposed soil suggests significant uptake of the heavy metals from the soil[6].

Our previous study[7] suggested that refuse dumps can substantially increase the environmental burden of heavy metals in Awka municipality, Nigeria. Soil contamination may adversely impact human health when agricultural produce grown in and around dump sites are contaminated, or when infiltration and surface runoff contribute to ground and surface water contamination. Because organic and inorganic compounds that contain heavy metals are common at refuse dump sites in Awka, they degrade and decompose following favorable weather conditions, thereby releasing various pollutants into the soil and ground water.

In this follow-up study, we investigated if heavy metal levels of farm produce harvested from refuse dump sites in Awka positively correlated with soil samples in the same locations. Heavy metal levels of ground and surface water within the study areas, changes in soil properties, and bacterial isolates are also presented.

\section{METHODS}

We sampled the five biggest refuse dump sites in Awka (Fig. 1, labeled sites A-E). These sites are mainly used for the dumping of domestic and sundry refuse. All the soil samples are fine to medium sand in texture. For consistency across sites, two soil samples were collected in ring form at the surface and at a depth of $1.35 \mathrm{~m}$, and stored in black polyethylene bags before digestion and analysis. The temperature of the laboratory was $29.5^{\circ} \mathrm{C}+/-$ (ambient temperature). Samples were ground, mixed, and divided into fine particles that could pass through a 0.5 - $\mathrm{mm}$ sieve. Soil samples were digested by adding $2 \mathrm{~g}$ of soil to 15 $\mathrm{ml}$ of concentrated nitric acid and perchloric acid at a ratio 1:1, and allowed to stand for $135 \mathrm{~min}$ until the mixture became colorless. The samples were filtered and washed with $15 \mathrm{ml}$ of deionized water, and made up the filtrate to $100 \mathrm{ml}$ in a standard flask. Six heavy metals (lead, manganese, arsenic, chromium, cadmium, and nickel) were determined in the filtrate at their respective wavelengths using an atomic absorption spectrophotometer (AAS) 200A[7]. Heavy metals of surface and ground water were also determined using clean filtrates of the samples. The heavy metal levels of food samples, such as vegetables (spinach [Amanthus hydbridus], fluted pumpkin [Telfairia occidentals]) and root crop (cocoyam [Xanthosoma sagittifolium]), were determined after ashing and digestion. Linear regression and correlation coefficient between soil heavy metals and farm produce heavy metals were calculated.

Percentage organic matter (carbon) of surface soil at refuse dumps was determined according to Emedo et al.[8]. Exchangeable cations, such as potassium, sodium, and calcium, were determined on a flame photometer, while magnesium was determined with AAS. Bulk density, particle density, percentage porosity, and cation exchange capacity were determined[9]. Soil $\mathrm{pH}$ was determined by weighing $20 \mathrm{~g}$ of air-dried soil (passing through a 2-mm sieve) into a 50-ml beaker, then adding $20 \mathrm{ml}$ of distilled water, allowing to stand for $30 \mathrm{~min}$, while stirring occasionally with a glass rod. An electrode of the $\mathrm{pH}$ meter was inserted into the partly settled suspension and $\mathrm{pH}$ measured; the result was reported as "soil $\mathrm{pH}$ in water". For bacterial isolates, soil samples were collected in sterile specimen bottles from a depth of 0.05 $\mathrm{m}$ after scrapping the surface debris, and treated within $90 \mathrm{~min}$. The samples were air dried and sieved using a wire mesh. About $10 \mathrm{~g}$ of the sieve samples was mixed in $10 \mathrm{ml}$ of normal saline and serially diluted up to $10^{5}$, then $0.1 \mathrm{~m}$ of the sample was aseptically spread on freshly prepared nutrient agar plates, and incubated at $37^{\circ} \mathrm{C}$ for $24 \mathrm{~h}$. The plates were inverted, the colonies were subcultured onto freshly prepared nutrient agar plates, and incubated at $37^{\circ} \mathrm{C}$ for $24 \mathrm{~h}$. From the pure cultures, standard characterization tests, including gram stain, motility, and fermentation were carried out. The identification of the isolates was based on the method of Cruickshank et al.[10] and Holt[11]. Control samples were collected $100 \mathrm{~m}$ from the dump sites. In all, the triplicate samples agreed very well. The result given is the mean of three estimations and was analyzed statistically using the Student t-test. 


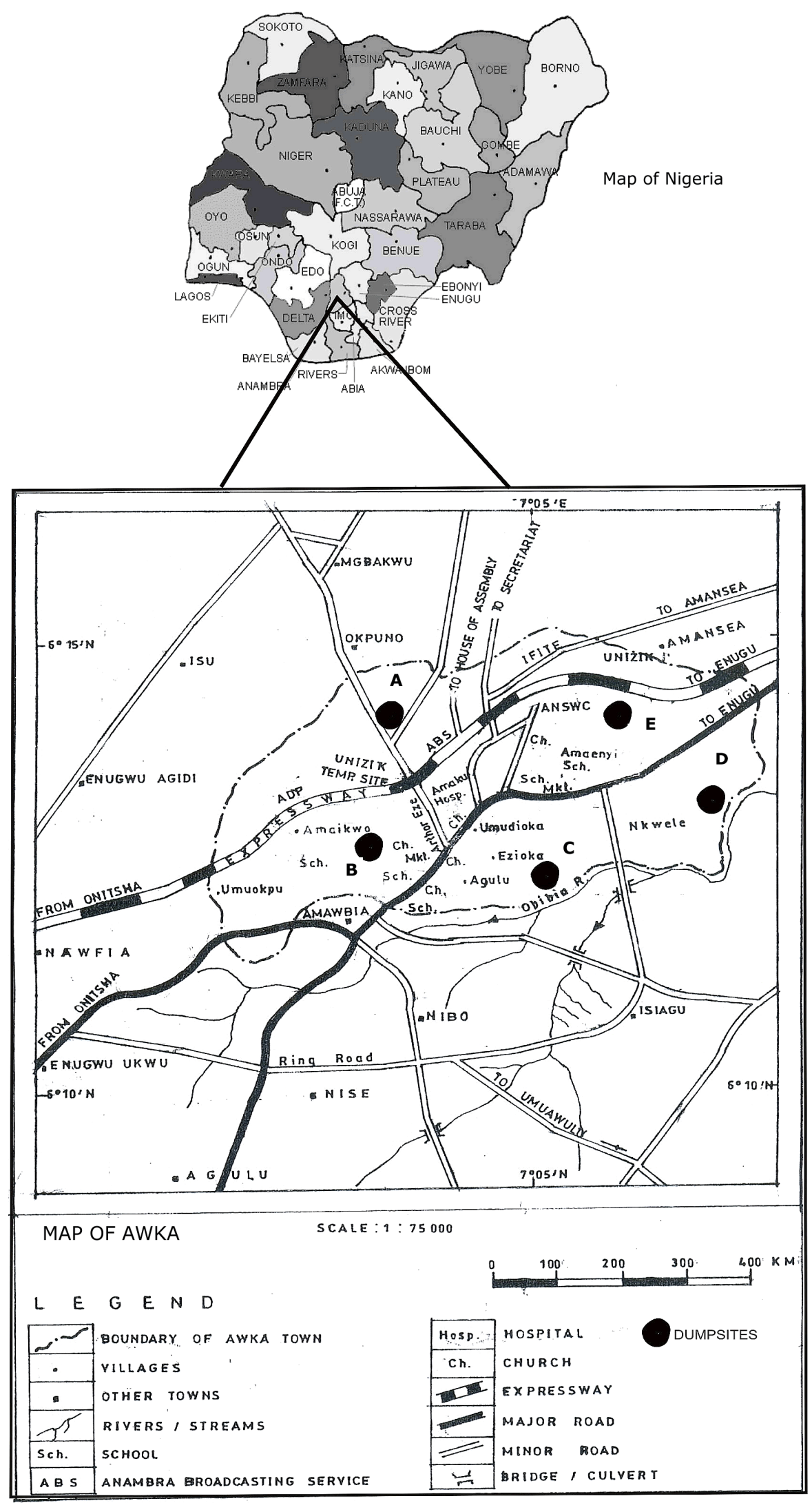

FIGURE 1. Map of Awka. 


\section{RESULTS}

Results indicate the presence of all the metals assessed. There were high levels of chromium, manganese, and nickel at the surface of site A. Lead and cadmium were more at the surface of site B; manganese and cadmium were found to be more at the surface of site $\mathrm{C}$; lead, arsenic, chromium, and cadmium at the surface of site D. Whereas manganese, arsenic, chromium, and nickel were found to be more at the surface of site E, most of these heavy metals were found to be more at a depth of $1.35 \mathrm{~m}$ (see Table 1). In all, only chromium showed a significant difference $(p<0.05)$ at the $1.35-\mathrm{m}$ depth.

TABLE 1

Metal Levels in $\mathrm{mg} / \mathrm{kg}$ of Soil at Different Dump Sites

\begin{tabular}{lccccccc}
\hline & Depth $(\mathbf{m})$ & $\mathbf{P b}$ & $\mathbf{M n}$ & $\mathbf{A s}$ & $\mathbf{C r}$ & $\mathbf{C d}$ & $\mathbf{N i}$ \\
\hline Site A & 0.00 & $350(83.8)$ & 290 & $620(\mathrm{ND})$ & 4.75 & 2.00 & $27.00(\mathrm{ND})$ \\
& 1.35 & 510 & 280.5 & 350 & 4.00 & 3.00 & 21.00 \\
Site B & 0.00 & $500(\mathrm{ND})$ & 135 & $30(\mathrm{ND})$ & 2.17 & 2.85 & $18.95(\mathrm{ND})$ \\
& 1.35 & 350 & 160 & 65 & 2.50 & 2.38 & 31.50 \\
Site C & 0.00 & $620(\mathrm{ND})$ & 120 & $102(\mathrm{ND})$ & 2.35 & 2.66 & $15.00(\mathrm{ND})$ \\
& 1.35 & 613.50 & 105 & $\mathrm{ND}$ & 2.43 & 2.57 & 18.00 \\
Site D & 0.00 & $401(3.80)$ & 55.70 & $31.85(\mathrm{ND})$ & 2.63 & 2.80 & $64.50(\mathrm{ND})$ \\
& 1.35 & 370 & 60.55 & $\mathrm{ND}$ & 2.62 & 1.79 & 68.35 \\
Site E & 0.00 & $145.30(\mathrm{ND})$ & 205 & $160(\mathrm{ND})$ & 3.09 & 2.14 & $61.75(\mathrm{ND})$ \\
& 1.35 & 160.30 & 136.85 & 65.90 & 2.43 & 3.15 & 46.50 \\
\hline
\end{tabular}

$\mathrm{ND}=$ Not detected, control values are in parentheses

Table 2 shows the concentration of heavy metals (mg/l) of shallow/hand dug (S) and borehole (B) well water. Manganese was found to be high in both shallow/hand dug and borehole water samples with highest levels as 0.538 and $0.325 \mathrm{mg} / \mathrm{l}$, respectively. Nickel levels in the borehole sample ranged from 0.001 to $0.227 \mathrm{mg} / \mathrm{l}$, whereas the highest level of lead was $0.01 \mathrm{mg} / \mathrm{l}$. The concentrations of metals in nearby streams, namely Okpuno, Ezu, and Obibia, are shown on Table 3. Obibia had the highest levels of heavy metals, 1.91 and $0.01 \mathrm{mg} / \mathrm{l}$ of manganese and lead, respectively.

Table 4 shows the heavy metal levels in food samples, such as vegetables (spinach [Amanthus hydbridus], fluted pumpkin [Telfairia occidentals]) and root crop (cocoyam [Xanthosoma sagittifolium]). With the exception of spinach, all the food samples contained measurable levels of iron, lead, manganese, arsenic, chromium, cadmium, and nickel; fluted pumpkin contained the highest levels of these heavy metals.

Linear regression analyses showed that the relationship between soil heavy metals and farm produce heavy metals was strong.

Chemical tests show the presence of exchangeable cation and exchange capacity in an amount that will make nutrients available to plants (Table 5). Bacteria isolates from the dump sites are shown on Table 6. Staphylococcus aureus, Pseudomonas sp., Streptococcus sp; Escherichia coli, and Proteus sp. were seen at all the dump sites. Bacillus sp. and Klebsiella sp. were not detected in dump sites B and C.

\section{DISCUSSION}

Accumulation of heavy metals by crop plants from contaminated soils may pose health risks[12]. Plant shoots have been found to be contaminated by heavy metals, particularly cadmium, chromium, nickel, and 
TABLE 2

Concentration of Heavy Metals (mg/l) of Shallow/Hand Dug (S) and Borehole (B) Well Water

\begin{tabular}{|c|c|c|c|c|c|c|c|c|c|c|c|}
\hline $\begin{array}{l}\mathrm{Pb} \\
\text { (S) }\end{array}$ & $\begin{array}{l}\mathrm{Pb} \\
\text { (B) }\end{array}$ & $\begin{array}{l}\text { Mn } \\
\text { (S) }\end{array}$ & $\begin{array}{l}M n \\
\text { (B) }\end{array}$ & $\begin{array}{l}\text { As } \\
\text { (S) }\end{array}$ & $\begin{array}{l}\text { As } \\
\text { (B) }\end{array}$ & $\begin{array}{l}\mathrm{Cr} \\
\text { (S) }\end{array}$ & $\begin{array}{c}\mathrm{Cr} \\
\text { (B) }\end{array}$ & $\begin{array}{l}\text { Cd } \\
\text { (S) }\end{array}$ & $\begin{array}{l}\text { Cd } \\
\text { (B) }\end{array}$ & $\begin{array}{c}\mathrm{Ni} \\
\text { (S) }\end{array}$ & $\begin{array}{c}\mathrm{Ni} \\
\text { (B) }\end{array}$ \\
\hline ND & 0.008 & 0.250 & 0.271 & ND & ND & ND & ND & ND & 0.005 & 0.002 & 0.227 \\
\hline ND & ND & 0.101 & 0.325 & - & - & - & - & ND & 0.001 & ND & 0.008 \\
\hline ND & ND & ND & 0.121 & - & - & - & - & ND & ND & ND & $N D$ \\
\hline ND & 0.008 & 0.385 & 0.072 & - & - & - & - & $N D$ & ND & 0.005 & 0.005 \\
\hline 0.008 & ND & 0.173 & 0.037 & - & - & - & - & 0.002 & 0.001 & ND & 0.008 \\
\hline 0.008 & ND & 0.084 & 0.167 & - & - & - & - & 0.003 & 0.005 & ND & ND \\
\hline ND & ND & 0.036 & 0.065 & - & - & - & - & $N D$ & 0.001 & 0.008 & ND \\
\hline ND & 0.01 & 0.538 & 0.03 & - & 0.01 & - & 0.01 & 0.001 & 0.001 & 0.016 & 0.001 \\
\hline 0.008 & 0.01 & 0.005 & 0.03 & - & 0.01 & - & 0.001 & 0.005 & 0.001 & ND & 0.001 \\
\hline- & 0.01 & - & 0.07 & - & 0.01 & - & 0.001 & - & 0.001 & - & 0.001 \\
\hline- & 0.01 & - & 0.05 & - & 0.01 & - & 0.001 & - & 0.001 & - & 0.001 \\
\hline
\end{tabular}

ND $=$ Not detected

TABLE 3

Concentration of Metals $(\mathrm{mg} / \mathrm{l})$ in Nearby Streams

\begin{tabular}{lcccccc}
\hline Name of Stream & $\mathbf{P b}$ & $\mathbf{M n}$ & $\mathbf{A s}$ & $\mathbf{C r}$ & $\mathbf{C d}$ & $\mathbf{N i}$ \\
\hline Okpuno & $\mathrm{ND}$ & 0.015 & $\mathrm{ND}$ & $\mathrm{ND}$ & 0.003 & $\mathrm{ND}$ \\
Ezu & 0.001 & 0.02 & 0.001 & 0.001 & 0.001 & 0.001 \\
Obibia & 0.01 & 1.91 & 0.001 & 0.01 & 0.01 & 0.03 \\
\hline
\end{tabular}

$\mathrm{ND}=$ Not detected

TABLE 4

Concentration of Metals in $\mathrm{mg} / \mathrm{kg}$ of Food Harvested from Dump Sites

\begin{tabular}{lcccccc}
\hline Food Type & Pb & Mn & As & Cr & Cd & Ni \\
\hline Spinach (Amanthus hydbridus) & 1.30 & 9.67 & ND & 3.88 & 0.67 & 1.06 \\
Fluted pumpkin (Telfairia occidentals) & 1.74 & 20.57 & 0.10 & 0.10 & 1.55 & 1.65 \\
Cocoyam (Xanthosoma sagittifolium) & 0.10 & 0.10 & 0.10 & 0.01 & 0.05 & 0.77 \\
\hline
\end{tabular}

$\mathrm{ND}=$ Not detected

lead, in amounts that exceed the guidance limits set by State Environmental Protection Protection (SEPA), China and the World Health Organization[12]. The present study investigated the environmental impact of the refuse dump sites with a capture of the heavy metal levels in potable water and food samples - like spinach (Amanthus hydbridus), fluted pumpkin (Telfairia occidentals), and cocoyam (Xanthosoma sagittifolium), which form the staple food of the local population. 
TABLE 5

Chemical Properties of Surface Soil at the Dump Sites

\begin{tabular}{lcccccc}
\hline & \multicolumn{7}{c}{ Parameters* $^{*} \begin{array}{c}\text { Surface Soil } \\
\text { Sample of } \\
\text { Different Sites }\end{array}$} & $\begin{array}{c}\text { Cation } \\
\text { Exchange } \\
\text { Capacity } \\
\left(\mathbf{c m o l}_{\mathbf{c}} \mathbf{k g}\right)\end{array}$ & $\begin{array}{l}\text { Particle } \\
\text { Density } \\
\left(\mathbf{m g} / \mathbf{m}^{\mathbf{3}}\right)\end{array}$ & $\begin{array}{c}\text { Bulk } \\
\text { Density } \\
\left(\mathbf{m g} / \mathbf{m}^{\mathbf{3}}\right)\end{array}$ & $\mathbf{p H}$ & $\begin{array}{c}\text { \% Pore } \\
\text { Space }\end{array}$ & $\begin{array}{c}\% \\
\text { Organic } \\
\text { Matter }\end{array}$ \\
\hline Site A & $7.66(3.32)$ & $2.55(2.65)$ & $1.78(1.73)$ & $6.61(6.22)$ & $30.20(34.72)$ & $2.55(0.00)$ \\
Site B & $6.16(4.04)$ & $2.50(2.70)$ & $1.88(1.83)$ & $6.62(4.45)$ & $24.80(32.22)$ & $1.72(0.79)$ \\
Site C & $5.92(3.16)$ & $2.60(2.75)$ & $1.83(1.73)$ & $6.69(5.26)$ & $29.62(37.09)$ & $1.45(0.00)$ \\
Site D & $6.56(4.24)$ & $2.80(2.55)$ & $1.83(1.78)$ & $6.68(6.38)$ & $34.64(30.20)$ & $2.10(0.86)$ \\
Site E & $7.48(3.04)$ & $2.75(2.65)$ & $1.68(1.73)$ & $6.60(6.65)$ & $38.90(34.72)$ & $3.07(0.00)$ \\
\hline
\end{tabular}

* $\quad$ Control values in parentheses.

TABLE 6

Bacteria Isolates from the Dump Sites

\begin{tabular}{lccccc}
\hline Bacteria & Site A & Site B & Site C & Site D & Site E \\
\hline Staphylococcus aureus & Present & Present & Present & Present & Present \\
Pseudomonas sp. & Present & Present & Present & Present & Present \\
Streptococcus sp. & Present & Present & Present & Present & Present \\
Escherichia coli & Present & Present & Present & Present & Present \\
Bacillus sp. & Present & Absent & Absent & Present & Present \\
Klebsiella sp. & Present & Absent & Absent & Present & Present \\
Proteus sp. & Present & Present & Present & Present & Present \\
\hline
\end{tabular}

Heavy metal levels as in our previous study[7] were found to be higher at the 1.35-m depth. Soil porosity, a shallow water table, and high annual rainfall facilitate rapid leaching and infiltration into the underground water. In part, this may explain the high level of some of these metals at the 1.35-m depth. The high content of these metals is less surprising, as some are associated with organic compounds that are common at the dump sites. Manganese was found to be high in both shallow/hand dug and borehole well water samples, with the highest levels as 0.538 and $0.325 \mathrm{mg} / \mathrm{l}$, respectively. Nickel levels in the borehole sample ranged from 0.001 to $0.227 \mathrm{mg} / \mathrm{l}$, whereas the highest level of lead was $0.01 \mathrm{mg} / \mathrm{l}$. The Obibia stream had the highest levels of heavy metals, 1.91 and $0.01 \mathrm{mg} / \mathrm{l}$ of manganese and lead, respectively. The levels of these heavy metals were below the U.S. Environmental Protection Agency's maximum contaminant level (USEPA MCL; MCL for lead is $0.015 \mathrm{mg} / \mathrm{l}$, that of cadmium is $0.005 \mathrm{mg} / \mathrm{l}$ ).

With the exception of spinach, all the food samples contained measurable levels of lead, manganese, arsenic, chromium, cadmium, and nickel. Fluted pumpkin contained the highest levels of these heavy metals. The entry of these heavy metals into the food chain has important public health implications. In 2004, Orisakwe and coworkers[13] reported high levels of lead in aerial fruits near an industrial area in Nigeria.

Chemical tests revealed the presence of exchangeable cations and exchange capacity in an amount that will make nutrients available to plants. Cation exchange capacity (the sum total of the exchangeable cations that a soil can adsorb) is a function of a variety of soils and soil materials; humus soil (with high organic matter) has high cation exchange capacity (CEC). This is evident in our results and is also 
supported by literature[9]. A combination of biological processes (decomposition and accumulation), carbon (iv) oxide $\left(\mathrm{CO}_{2}\right)$, methane $\left(\mathrm{CH}_{4}\right)$, and nitrous oxide $\left(\mathrm{N}_{2} \mathrm{O}\right)$ are generated. The cation exchange of most soils increases with $\mathrm{pH}$. At very low $\mathrm{pH}$ values, the CEC is also generally low; as the $\mathrm{pH}$ is raised (alkalinity), CECs increase. To obtain a measure of this maximum retentive capacity, the CEC is commonly determined at $\mathrm{pH} 7$ or above. By cation exchange, nutrient cations are forced into soil solutions where they are available for root hairs. The acidity of the top soil at dump sites and that of the control does not vary much because of high exchangeable cations, such as sodium, magnesium, calcium, and potassium, previously reported from our laboratory[7], which are not highly leachable (when leached, they are replaced by hydrogen ion) because most components of the studied dump sites have been found to contain high levels of these metals[14].

In their studies that evaluated cancer and noncancer health effects from eating cassava grown in the mining areas of Ghana in accordance with the USEPA Risk Assessment guidelines, Obiri et al.[2] found cancer health risk values above the acceptable cancer risk range. Tandi et al.[6] concluded that long-term addition of sewage sludge/effluent to farm soils increased the concentration of zinc and copper in top soil to levels that pose environmental concern. Our study is in agreement with the work of Khan and coworkers[12] that there may be potential health risks associated with cultivation and consumption of crops and vegetables grown on contaminated soils. The soil uptake of the heavy metals may probably be related to the differences in organic matter of the soils.

Heavy metals in food samples were positively correlated with soil levels indicating soil contamination. Although the present study implicates soil contamination, we also suggest further studies to investigate diffuse pollution by aerial deposition due to the presence of smog in the city. Taken together and in comparison with other studies, we may conclude that the consumption of leafy vegetables and root crops produced on contaminated soils poses a health risk to poor communities that reside around the refuse dump sites.

Staphylococcus aureus, Pseudomonas sp., Streptococcus sp., Escherichia coli, Bacillus sp., Klebsiella sp., and Proteus sp. were isolated from all the dump sites, except sites B and C where Bacillus and Klebsiella were not found. These bacteria have been variously reported in dump site studies. E. coli and Streptococcus sp. have been reported by Ekundayo[15], while Bacillus sp., E. coli, Pseudomonas sp., and Klebsiella sp. have been reported by Cook et al.[16]. Pseudomonas sp. has been widely reported to be associated with waste[17]. All the bacteria isolated have been reported as potential pathogens by Cook et al.[16].

Since the dumps are within residential areas, and there are no landfills in Awka and in most Nigerian cities, domestic animals and nocturnal insects can serve as vectors of these pathogens. Whereas the refuse dump sites may not be very important in the overall heavy metal pollution of the potable water supply, it is evidenced in the present study that refuse dump sites impact positively on the heavy metal contamination of food samples like vegetables, such as spinach (Amanthus hydbridus) and fluted pumpkin (Telfairia occidentals), and root crops, such as cocoyam (Xanthosoma sagittifolium), in Awka, Nigeria. This entry and eventual contamination of the food chain has caused a serious public health concern.

\section{REFERENCES}

1. Ingwersen, J. and Streck, T. (2006) Modeling the environmental fate of cadmium in a large wastewater irrigation area. J. Environ. Qual. 35(5), 1702-1714.

2. Obiri, S., Dodoo, D.K., Okai-Sam, F., Essumang, D.K., and Adjorlolo-Gasokpoh, A. (2006) Cancer and non-cancer health risk from eating cassava grown in some mining communities in Ghana. Environ. Monit. Assess. 118(1-3), $37-49$.

3. Sukkariyah, B.F., Evanylo, G., Zelazny, L., and Chaney, R.L. (2005) Cadmium, copper, nickel, and zinc availability in a biosolids-amended piedmont soil years after application. J. Environ. Qual. 34(6), 2255-2262.

4. Feng, X., Li, G., and Qiu, G. (2006) A preliminary study on mercury contamination to the environment from artisanal zinc smelting using indigenous methods in Hezhang County, Guizhou, China: Part 2. Mercury contaminations to soil and crop. Sci. Total Environ. 368(1), 47-55. 
5. Shute, T. and Macfie, S.M. (2006) Cadmium and zinc accumulation in soybean: a threat to food safety? Sci. Total Environ. 371(1-3), 63-73.

6. Tandi, N.K., Nyamangara, J., and Bangira, C. (2004) Environmental and potential health of growing leafy vegetables on soil irrigated using sewage sludge and effluent: a case of $\mathrm{Zn}$ and Cu. J. Environ. Sci. Health B 39(3), 461-471.

7. Nduka, J.K.C., Orisakwe, O.E., Ezenweke, L.O., Abiakam, C.O., Nwanguma, C.K., and Maduabuchi, J.-M.U. (2006) Metal contamination and infiltration into the soil at refuse dumpsites in Awka Nigeria. Arch. Environ. Health Occup. Health 61(5), 197-204.

8. Emedo, C., Jakande, T., and Aminu, U. (2001) Comprehensive Practical Agricultural Science for West African Senior Secondary School and Colleges. ${ }^{\text {st }}$ ed. Hybrid Publishers, Onitsha, Nigeria. pp. 20-23.

9. Brady, N.C. and Weil, R.R. (1999) The Nature and Properties of Soils. $12^{\text {th }}$ ed. Prentice-Hall, Englewood Cliffs, NJ. pp. 15-21, 134-138, 144-149, 328-334, 344-347, 446-489.

10. Cruickshank, R., Duguid, R.P., Marmion, B.P., and Swain, R.H.A. (1975) Medical Microbiology. $12^{\text {th }}$ ed. Churchill Livingstone, Edinburgh.

11. Holt, J.G., Ed. (1977) The Short Bergey's Manual of Determinative Bacteriology. $4^{\text {th }}$ ed. William and Wilkins, Baltimore.

12. Khan, S., Aijun, L., Zhang, S., Hu,Q., and Zhu ,Y.G. (2007) Accumulation of polycyclic aromatic hydrocarbons and heavy metals in lettuce grown in the soils contaminated with long-term wastewater irrigation. J. Hazard. Mater. 152(2), 506-515.

13. Orisakwe, O.E., Asomugha, R., Afonne, O.J., Anisi, C.N., Obi, E., and Dioka, C.E. (2004) Impact of effluents from car battery manufacturing plant on water, soil and food qualities in Nnewi, Nigeria. Arch. Environ. Health 59, 3136.

14. Orisakwe, O.E., Obi, E., Amilo, G., Dioka, C.E., Afonne, O.J., and Ufearo, C.S. (1997) Sodium and potassium levels and label review studies of Nigerian spices. Indian J. Nutr. Diet 37, 146-150.

15. Ekundayo, J.A. (1977) Environmental consequences of the pollution of the Lagos Lagoon. Bull. Sci. Assoc. Nigeria 3(2), 290-299.

16. Cook, H.A., Cromwell, D.L., and Wilson, H.A. (1964) Microorganisms in household refuse and seepage water from sanitary landfills. Proc. W. Va. Acad. Sci. 39, 107-114.

17. Sabry, S.A. (1992) Microbial degradation of shrimp shell waste. J. Basic Microbiol. 32(2), 107-111.

\section{This article should be cited as follows:}

Nduka ,J.K.C., Orisakwe, O.E, Ezenweke, L.O, Chendo, M.N., and Ezenwa, T.E (2008) Heavy metal contamination of foods by refuse dump sites in Awka, Southeastern Nigeria. TheScientificWorldJOURNAL 8, 941-948. DOI 10.1100/tsw.2008.129. 

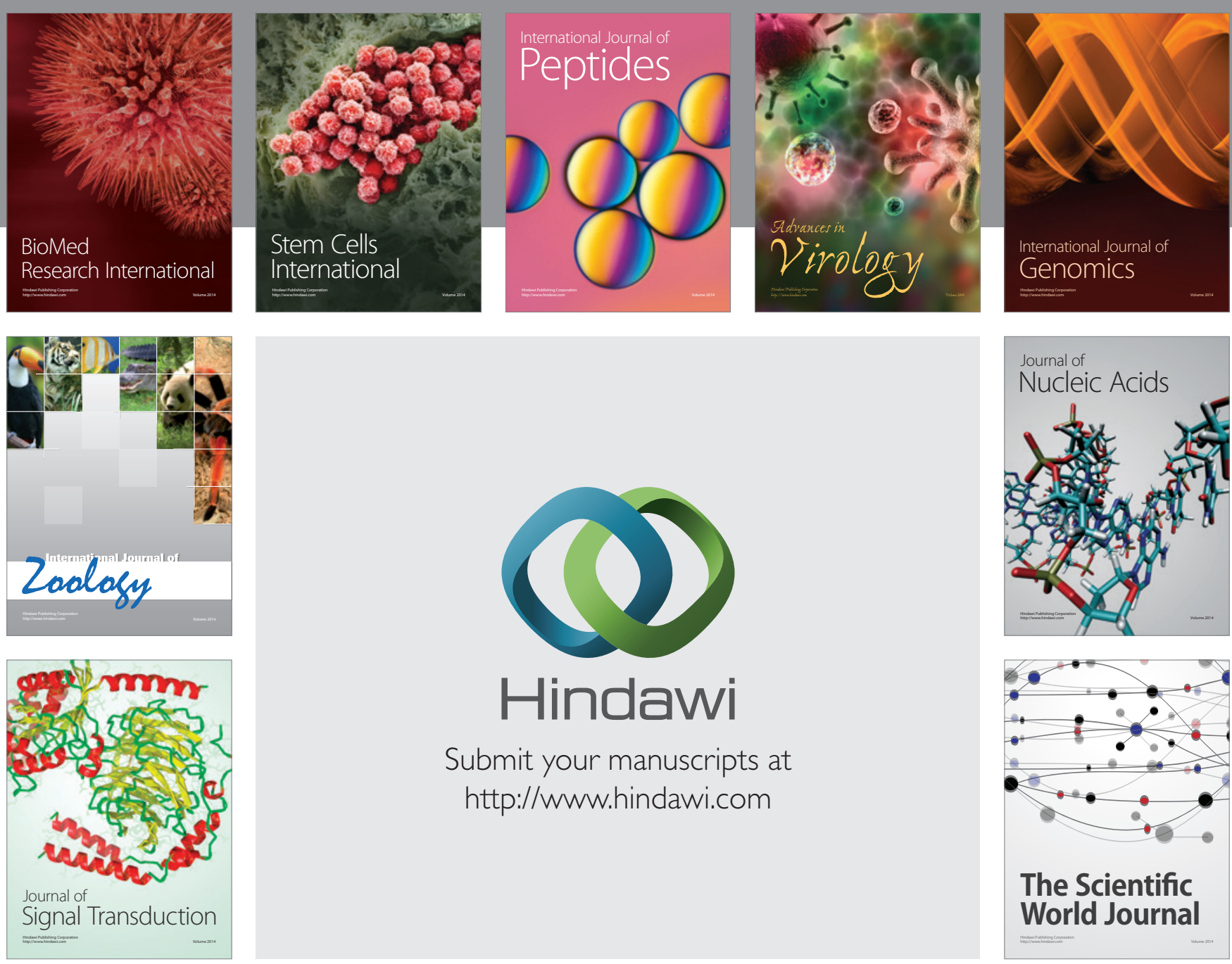

Submit your manuscripts at

http://www.hindawi.com
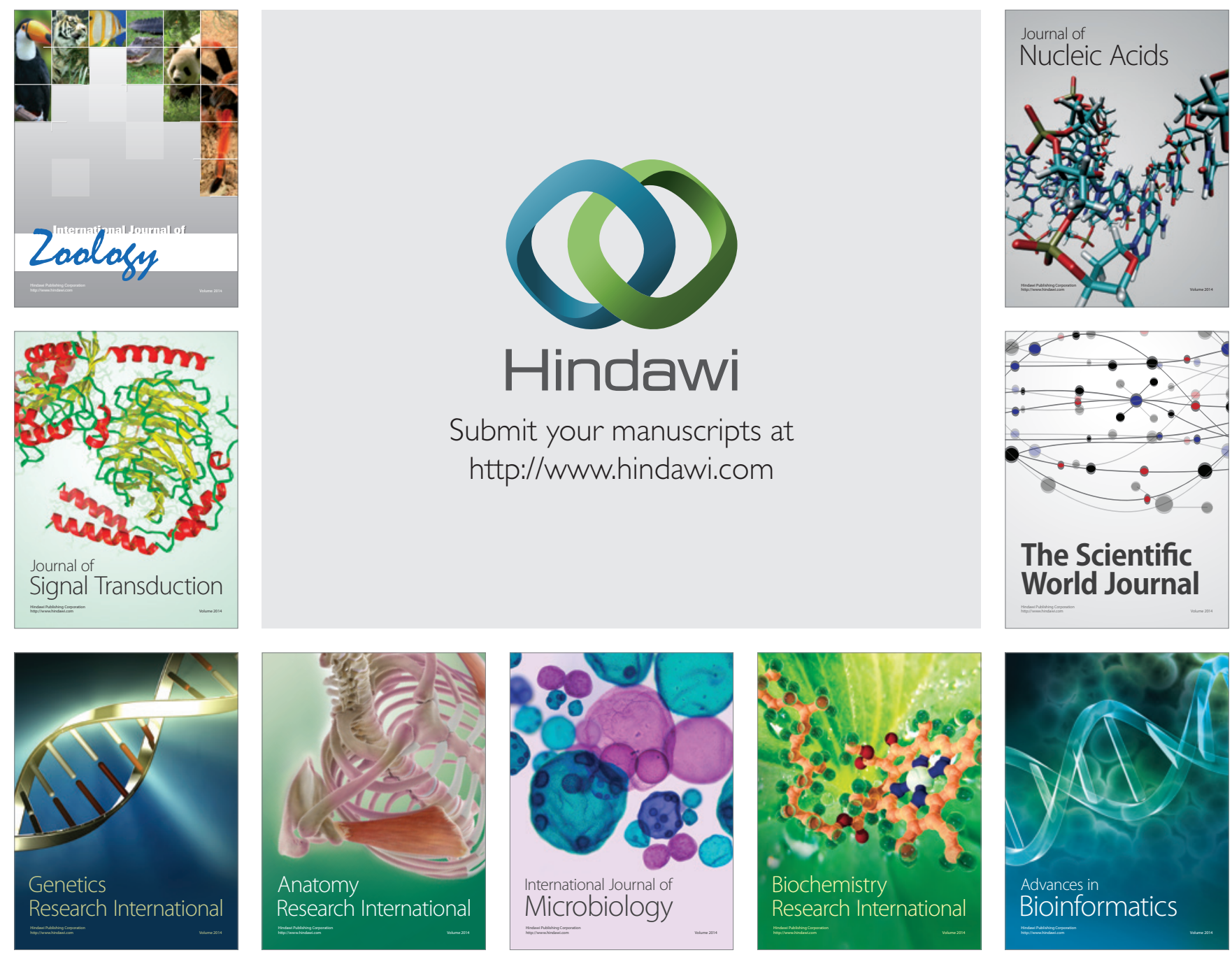

The Scientific World Journal
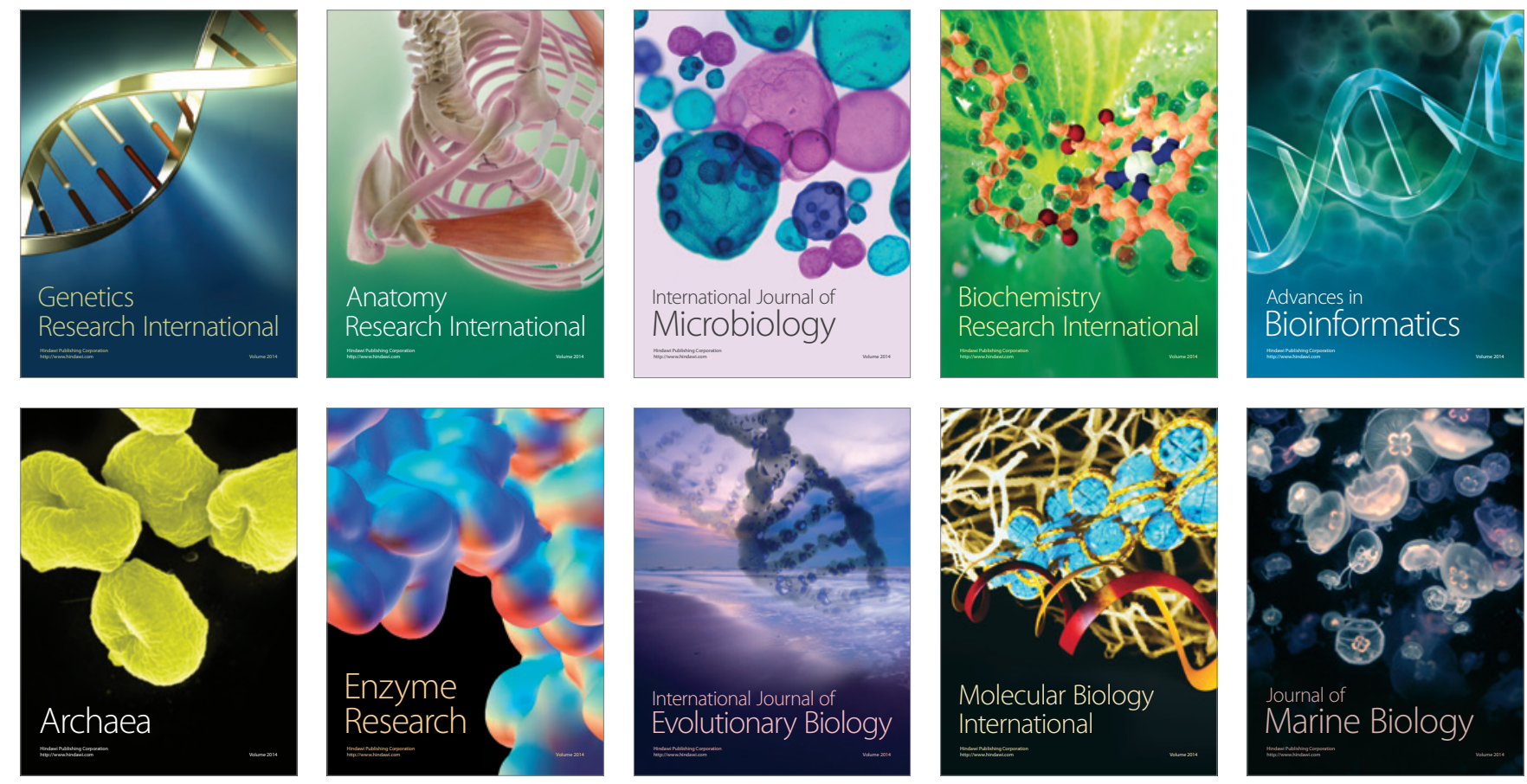